\title{
$\beta$-Elimination and insertion of CNR in transient pentamethylcyclopentadienyl-imido-tantalum dialkyl complexes. X-ray structure of $\left[\mathrm{TaCp}^{*}\left\{\mathrm{~N}\left(2,6-\mathrm{Me}_{2} \mathrm{C}_{6} \mathrm{H}_{3}\right)\right\}\left(\mathrm{CH}_{2}=\mathrm{CH}_{2}\right)\left(\mathrm{PMe}_{3}\right)\right]$
}

\author{
Pascual Royo ${ }^{\mathrm{a}, *}$, Javier Sánchez-Nieves ${ }^{\mathrm{a}}$, Maria Angela Pellinghelli ${ }^{\mathrm{b}}$, Antonio Tiripicchio ${ }^{\mathrm{b}}$ \\ a Departamento de Química Inorgánica, Facultad de Ciencias, Universidad de Alcalá, E-28871-Alcalá de Henares, Spain \\ ${ }^{\mathrm{b}}$ Dipartimento di Chimica Generale ed Inorganica, Chimica Analitica, Chimica Fisica, Università di Parma, \\ Centro di Studio per la Strutturistica Diffrattometrica del CNR, Viale delle Scienze, I-43100 Parma, Italy
}

Received 21 July 1997

\begin{abstract}
The transient dialkyl complexes $\left[\mathrm{TaCp} * \mathrm{R}_{2}(\mathrm{NAr})\right]\left(\mathrm{Cp}^{*}=\mathrm{C}_{5} \mathrm{Me}_{5} ; \mathrm{R}=\mathrm{Et}, n-\mathrm{Pr} ; \mathrm{Ar}=2,6-\mathrm{Me}_{2} \mathrm{C}_{6} \mathrm{H}_{3}\right)$, obtained by alkylation of [TaCp* $\left.\mathrm{Cl}_{2}(\mathrm{NAr})\right]$ with two equiv. of $\mathrm{RMgCl}$ in diethylether at low temperature, react with one equiv. of $\mathrm{PMe}_{3}$ to give $\left[\mathrm{TaCp} *(\mathrm{NAr})\left(\mathrm{CH}_{2}=\mathrm{CHR}\right)\left(\mathrm{PMe}_{3}\right)\right](\mathrm{R}=\mathrm{H} 1, \mathrm{Me} 2)$ after $\beta$-elimination and reductive elimination of alkane. When the same alkylation is carried out and then one equiv. of $\mathrm{CN}\left(2,6-\mathrm{Me}_{2} \mathrm{C}_{6} \mathrm{H}_{3}\right)$ is added after heating to room temperature, the alkyl iminoacyl insertion products $\left[\mathrm{TaCp} * \mathrm{R}\left\{\eta^{2}-\mathrm{CR}=\mathrm{N}(\mathrm{Ar})\right\}(\mathrm{NAr})\right](\mathrm{R}=\mathrm{Et} 3, n-\mathrm{Pr} 4)$ are obtained. However when alkylation with one equiv. of $\operatorname{MgClR}(\mathrm{R}=\mathrm{Et}, n-\mathrm{Pr}, i-\mathrm{Pr})$ is carried out at ambient temperature after the addition of $\mathrm{CN}\left(2,6-\mathrm{Me}_{2} \mathrm{C}_{6} \mathrm{H}_{3}\right)$, the chloro iminoacyl complexes $\left.\left[\mathrm{TaCp} * \mathrm{Cl}\left\{\eta^{2}-\mathrm{CR}=\mathrm{NAr}\right)\right\}(\mathrm{NAr})\right]\left(\mathrm{R}=\mathrm{Et} \mathbf{5}, n\right.$-Pr 6, $i$-Pr 7) are isolated. The structure of $\left[\mathrm{TaCp} *\left(\mathrm{NAr}^{2}\left(\mathrm{CH}_{2}=\mathrm{CH}_{2}\right)\right.\right.$ $\left.\left(\mathrm{PMe}_{3}\right)\right]$ (1) has been determined by X-ray diffraction methods. (C) 1998 Elsevier Science Ireland Ltd. All rights reserved.
\end{abstract}

Keywords: Alkyl; Imido; Iminoacyl; Pentamethylcyclopentadienyl; Tantalum

\section{Introduction}

There is increasing interest in the study of group 5 metal complexes containing the half sandwich cyclopentadienyl imido $\left[\mathrm{M}\left(\eta^{5}-\mathrm{C}_{5} \mathrm{R}_{5}\right)\left(\mathrm{NR}^{\prime}\right)\right]$ fragment because they offer the opportunity to make comparisons with the isolobal dicyclopentadienyl group 4 metal fragment $\left[\mathrm{M}\left(\eta^{5}-\mathrm{C}_{5} \mathrm{R}_{5}\right)_{2}\right][1]$, which has been shown to have important applications in organic synthesis [2] and olefin polymerization processes [3]. We have reported recently [4] novel aspects of the chemistry of doubly $\mathrm{SiMe}_{2}-$ bridged dicyclopentadienylzirconium complexes with $\beta$ hydrogen containing alkyl substituents and were interested in isolating similar group 5 metal compounds with the imido cyclopentadienyl fragment. The imido group is a useful stabilizing ligand for transition metal

* Corresponding author. Tel.: + 341 8854765; fax: + 341 8854683; e-mail: proyo@inorg.alcala.es complexes in high oxidation state [5]. Furthermore, systems with neutral organic molecules coordinated to the same metal center are useful as models for important catalytic processes [6]. Related imido-alkene niobium complexes and their -carbonyl and -acetylene derivatives were isolated by Gibson [7]a using the same $\beta$-hydride elimination and loss of alkane from diethyl and di- $n$-propyl niobium intermediates, and similar vanadium compounds have also been prepared by Teuben [7]b reducing the dichloro complexes with magnesium in the presence of the ligands.

We herein report the different behaviour observed for the complex [ $\left.\mathrm{TaCp}^{*} \mathrm{Cl}_{2}(\mathrm{NAr})\right]\left(\mathrm{Cp}^{*}=\mathrm{C}_{5} \mathrm{Me}_{5}, \mathrm{Ar}=\right.$ 2,6- $\left.\mathrm{Me}_{2} \mathrm{C}_{6} \mathrm{H}_{3}\right)$ in reactions with $\beta$-hydrogen containing alkylmagnesium reagents in the absence and presence of $\mathrm{PMe}_{3}$ and $\mathrm{CN}\left(2,6-\mathrm{Me}_{2} \mathrm{C}_{6} \mathrm{H}_{3}\right)$ and the $\mathrm{X}$-ray structure of the olefin phosphine complex $\left[\mathrm{TaCp} *(\mathrm{NAr})\left(\mathrm{CH}_{2}=\right.\right.$ $\left.\left.\mathrm{CH}_{2}\right)\left(\mathrm{PMe}_{3}\right)\right]$. 


\section{Results and discussion}

The alkylation of $\left[\mathrm{TaCp}^{*} \mathrm{Cl}_{2}(\mathrm{NAr})\right]\left(\mathrm{Cp}^{*}=\mathrm{C}_{5} \mathrm{Me}_{5}\right.$, $\left.\mathrm{Ar}=2,6-\mathrm{Me}_{2} \mathrm{C}_{6} \mathrm{H}_{3}\right)$ with $\beta$-hydrogen containing alkylmagnesium reagents always led to unstable compounds at room temperature. The addition of $\mathrm{MgClR}(\mathrm{R}=\mathrm{Et}$, $n$-Pr) to diethylether solutions of $\left[\mathrm{TaCp}^{*} \mathrm{Cl}_{2}(\mathrm{NAr})\right]$ at $-78^{\circ} \mathrm{C}$ did not produce any observable transformation but on heating the evolution of alkane was observed to give a solution which after evaporation of the solvent gave an intractable residue from which no identifiable organometallic compound could be recovered.

When the same reaction was carried out in the presence of one equiv. of $\mathrm{PMe}_{3}$, elimination of alkane was similarly observed, leading to solutions which after evaporation and recrystallization rendered the tantalum(III) complexes $\left[\mathrm{TaCp} *(\mathrm{NAr})\left(\mathrm{CH}_{2}=\mathrm{CHR}\right)\left(\mathrm{PMe}_{3}\right)\right]$ $(\mathrm{R}=\mathrm{H} \mathrm{1}, \mathrm{Me} 2)$ as yellow crystalline solids in $85 \%$ yield. The olefin compounds $[2,6]$ result from $\beta$-hydrogen activation with reductive elimination of alkane, to give the olefin adducts stabilized as 18 electron compounds by coordination of $\mathrm{PMe}_{3}$. Both complexes were characterized by elemental analysis and NMR spectroscopy and the molecular structure of complex $\mathbf{1}$ was determined by X-ray diffraction methods.

The structure of complex $\mathbf{1}$ is shown in Fig. 1 together with the atomic labelling scheme. Selected bond

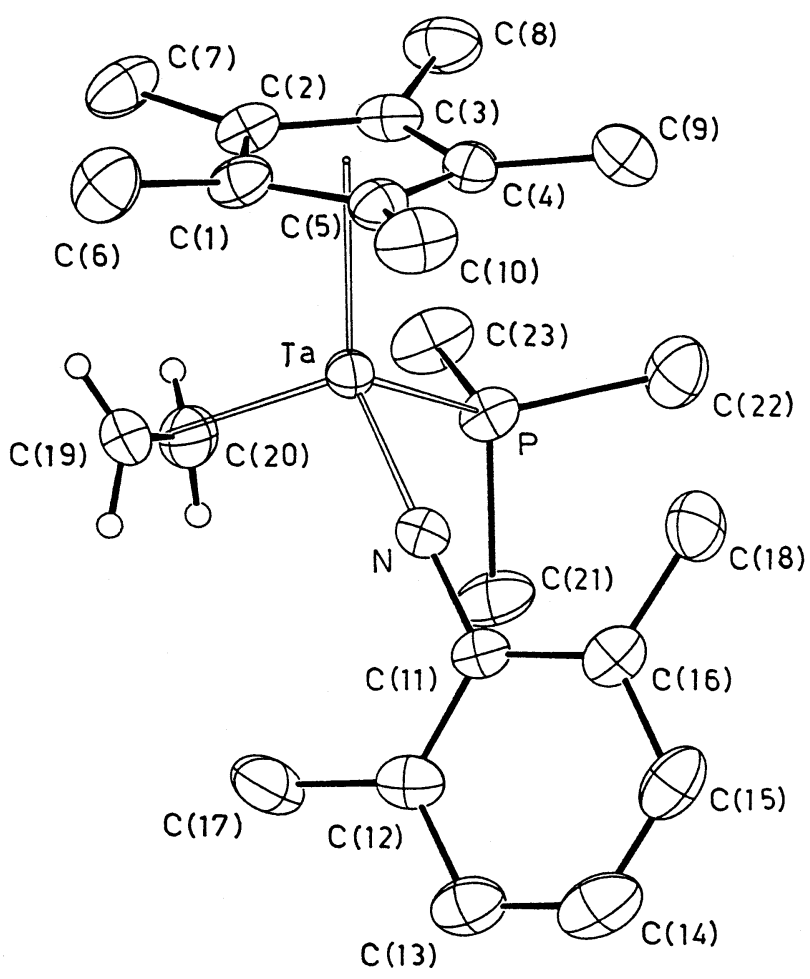

Fig. 1. Perspective view of the structure of the complex $\left[\mathrm{TaCp} *\left\{\mathrm{~N}\left(2,6-\mathrm{Me}_{2} \mathrm{C}_{6} \mathrm{H}_{3}\right)\right\}\left(\mathrm{CH}_{2}=\mathrm{CH}_{2}\right)\left(\mathrm{PMe}_{3}\right)\right]$ (1) with the atomic labelling scheme. The thermal ellipsoids are drawn at the $30 \%$ probability level.
Table 1

Selected bond lengths $(\AA)$ and angles $\left(^{\circ}\right)$ for complex 1

\begin{tabular}{lclc}
\hline $\mathrm{Ta}-\mathrm{CE}(1)$ & $2.164(6)$ & $\mathrm{Ta}-\mathrm{C}(19)$ & $2.231(8)$ \\
$\mathrm{Ta}-\mathrm{M}(1)$ & $2.119(8)$ & $\mathrm{Ta}-\mathrm{C}(20)$ & $2.245(8)$ \\
$\mathrm{Ta}-\mathrm{N}$ & $1.833(4)$ & $\mathrm{N}-\mathrm{C}(11)$ & $1.376(6)$ \\
$\mathrm{Ta}-\mathrm{P}$ & $2.545(2)$ & $\mathrm{C}(19)-\mathrm{C}(20)$ & $1.438(12)$ \\
$\mathrm{CE}(1)-\mathrm{Ta}-\mathrm{M}(1)$ & $113.3(3)$ & $\mathrm{M}(1)-\mathrm{Ta}-\mathrm{P}$ & $95.1(2)$ \\
$\mathrm{CE}(1)-\mathrm{Ta}-\mathrm{N}$ & $133.6(2)$ & $\mathrm{N}-\mathrm{Ta}-\mathrm{P}$ & $88.9(1)$ \\
$\mathrm{CE}(1)-\mathrm{Ta}-\mathrm{P}$ & $113.1(2)$ & $\mathrm{Ta}-\mathrm{N}-\mathrm{C}(11)$ & $176.5(4)$ \\
$\mathrm{M}(1)-\mathrm{Ta}-\mathrm{N}$ & $104.2(3)$ & &
\end{tabular}

$\mathrm{CE}(1)$ is the centroid of the $\mathrm{C}(1) \ldots \mathrm{C}(5)$ cyclopentadienyl ring and $\mathrm{M}(1)$ the midpoint of the double $\mathrm{C}(19)-\mathrm{C}(20)$ bond.

distances and angles are given in Table 1. The tantalum is bound to a pentamethylcyclopentadienyl ring in a slightly asymmetric $\eta^{5}$-fashion; the $\mathrm{Ta}(1)-\mathrm{C}$ distances range from $2.403(6)$ to $2.550(5) \AA)$, the distance between the metal and the centroid $\mathrm{CE}(1)$ of the ring being of 2.164(6) $\AA$. The Ta-CE(1) distance is close to those found in comparable $\mathrm{Ta}$ complexes as TaCp* $\mathrm{Cl}_{2}(\mathrm{NAr}), \quad 2.115(6) \AA[8](\mathrm{a}), \quad \mathrm{TaCp} * \mathrm{Me}(\mathrm{NAr})$ [NAr $-\mathrm{CMe}=\mathrm{CMe}_{2}$ ], 2.179(7) $\AA$ [8](b) and TaCp*Me(NAr) $\left[\eta^{2}-\mathrm{NAr}=\mathrm{C}-\mathrm{CMe}_{2}-\mathrm{CMe}=\mathrm{NAr}\right], \quad 2.155(11) \quad \AA$ [8](b), the shortest one is probably related to the presence of less hindered ligands.

The Ta atom is bound also to one $\mathrm{P}$ atom from the $\mathrm{PMe}_{3}$ ligand $[\mathrm{Ta}-\mathrm{P}=2.545(2) \AA]$, to the $\mathrm{N}$ atom from the phenylimido ligand $[\mathrm{Ta}-\mathrm{N}=1.833(4) \AA]$ and to the $\mathrm{C}(19)$ and $\mathrm{C}(20)$ atoms from the $\eta^{2}$-coordinating ethylene molecule $[\mathrm{Ta}-\mathrm{C}(19)$ and $\mathrm{Ta}-\mathrm{C}(20)=2.231(8)$ and $2.245(8) \AA$, respectively, $\mathrm{Ta}-\mathrm{M}(1)=2.119(8) \AA$, $\mathrm{M}(1)$ is the midpoint of the $\mathrm{C}(19)-\mathrm{C}(20)$ bond]. The olefinic C(19)-C(20) bond distance, 1.438(12) $\AA$ is, as expected, much longer than that corresponding to a double bond, because of the $\eta^{2}$-bonding to the metal.

The coordination geometry around the Ta atom can be described as of three legged piano stool type or as pseudotetrahedral if the centroid of the $\mathrm{Cp}^{*}$ ring and the midpoint of the $\mathrm{C}(19)-\mathrm{C}(20)$ bond are considered as occupying coordination sites. The complex is chiral and in the crystals both enantiomers are present. The values of the Ta-N bond length, 1.833(4) $\AA$, and of the $\mathrm{Ta}-\mathrm{N}-\mathrm{C}(11)$ angle, $176.5(4)^{\circ}$, are as expected for an imido ligand and comparable with those found for the same phenylimido ligand in $\mathrm{TaCp} * \mathrm{Cl}_{2}(\mathrm{NAr}), 1.774(5)$ $\AA$ and $169.9(5)^{\circ}[8](\mathrm{a})$, in $\mathrm{TaCp} * \mathrm{Me}(\mathrm{NAr})[\mathrm{NAr}-\mathrm{CMe}=$ $\left.\mathrm{CMe}_{2}\right], 1.784(4) \AA$ and $168.0(4)^{\circ}$ [8](b), and in $\mathrm{TaCp} * \mathrm{Me}(\mathrm{NAr})\left[\eta^{2}-\mathrm{NAr}=\mathrm{C}-\mathrm{CMe}_{2}-\mathrm{CMe}=\mathrm{NAr}\right], \quad 1.812$ (8) $\AA$ and $171.1(8)^{\circ}[8] \mathrm{b}$.

The ${ }^{1} \mathrm{H}-\mathrm{NMR}$ spectrum of complex 1 shows only one resonance at $\delta 2.41$ for the two methyl groups of the imido-aryl ligand in spite of their expected diastereotopic character due to the presence of the chiral metal center. Complex $\mathbf{2}$ with a similar structural disposition as the niobium derivative [7]a could be 


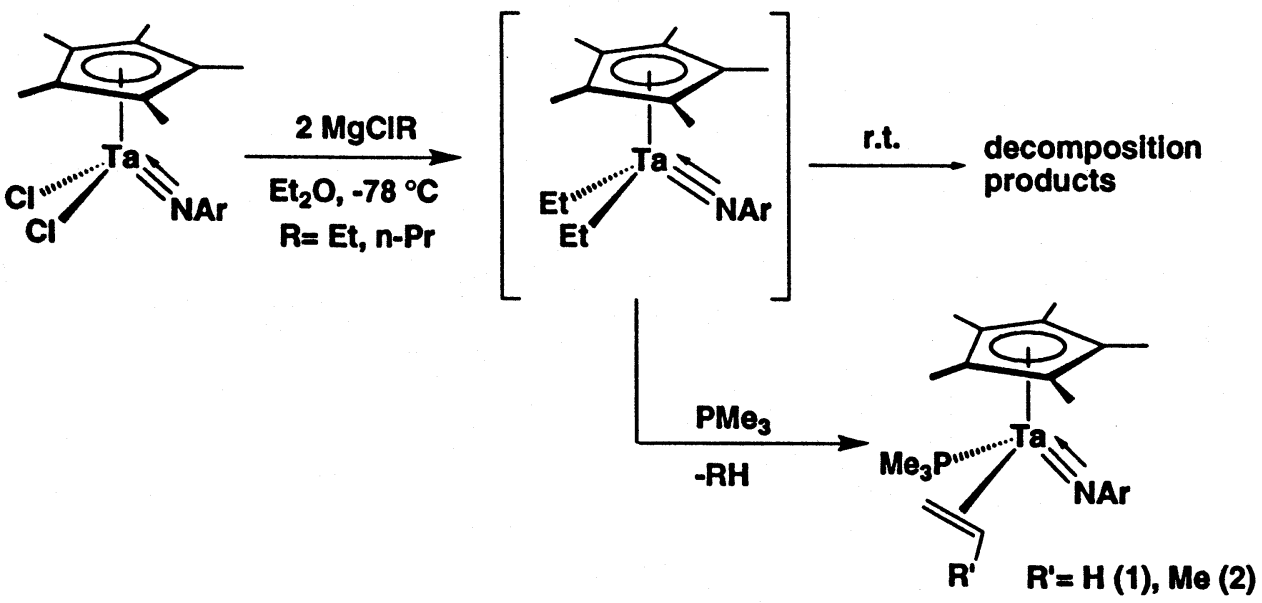

Scheme 1.

expected to form four similar isomers, depending on the endo or exo and syn or anti disposition of the methyl group of the propene ligand. However only one of these isomers was the major product (see Section 3) and a second one $(<20 \%)$ was observed by ${ }^{1} \mathrm{H}-\mathrm{NMR}$ spectroscopy after washing the resulting product with hexane, although minor unrecoverable amounts of the other isomers may also be present.

The presence of the bulkier pentamethylcyclopentadienyl group and the different steric requirements of the alkylimido and the trimethylphosphine ligands justify the preferential formation of the major component.

To confirm the proposed intermediate formation of the dialkyl complexes, we decided to study similar reactions using 1 equiv. of $\mathrm{CN}\left(2-6-\mathrm{Me}_{2} \mathrm{C}_{6} \mathrm{H}_{3}\right)$ as the free ligand, for which a simultaneous very rapid insertion reaction into the tantalum-alkyl bonds could be expected [9] (see Scheme 1). Addition of two equiv. of the alkylating agent at $-78^{\circ} \mathrm{C}$ to a toluene solution of $\left[\mathrm{TaCp} * \mathrm{Cl}_{2}(\mathrm{NAr})\right]$ followed by heating at room temperature and then addition of one equiv. of the isocyanide led to the iminoacyl derivatives $\left[\mathrm{TaCp} * \mathrm{R}\left\{\eta^{2}-\right.\right.$ $\left.\left.\mathrm{CR}=\mathrm{N}\left(2,6-\mathrm{Me}_{2} \mathrm{C}_{6} \mathrm{H}_{3}\right)\right\}\left\{\mathrm{N}\left(2,6-\mathrm{Me}_{2} \mathrm{C}_{6} \mathrm{H}_{3}\right)\right\}\right](\mathrm{R}=\mathrm{Et} \mathbf{3}, n-$ $\operatorname{Pr} 4)$ which were isolated as pale yellow air sensitive solids partially soluble in alkanes.

The coordination of the iminoacyl nitrogen to give the 18 electron compounds is responsible of the stability of the ethyl-tantalum complex, which does not decompose through $\beta$-hydrogen elimination. Formulation of complexes $\mathbf{3}$ and $\mathbf{4}$ is consistent with their analytical composition and the behaviour observed by ${ }^{1} \mathrm{H}$ and ${ }^{13} \mathrm{C}$-NMR spectroscopy. Both complexes contain a chiral tantalum center which is responsible for the diastereotopic behaviour observed in their ${ }^{1} \mathrm{H}-\mathrm{NMR}$ spectra for the methylenic protons of the metal- and iminoacyl carbon-bonded ethyl ligands and the two methyl groups of the imido- and iminoacyl nitrogenbonded aryl groups (see Section 3). The methylenic protons of the metal-bonded alkyl groups appear as two multiplets at $\delta 0.74(\mathrm{Et}), 0.80(n-\mathrm{Pr})$ and $\delta 1.45$ (Et), 1.41 ( $n$-Pr) due to their coupling with the methyl and methylene groups, respectively, whereas the iminoacyl carbon-bonded methylenic protons are observed as two multiplets at $\delta 2.47(\mathrm{Et}), 2.58(n-\mathrm{Pr})$ and $\delta 2.89$ (Et), $3.01(n-\mathrm{Pr})$. The methyl groups of the imidoaryl ligand appear as one broad resonance at $\delta 2.46(\mathrm{Et})$, $2.47(n-\mathrm{Pr})$ and those of the iminoacyl nitrogen-bonded aryl are observed as two singlets at $\delta 1.71(\mathrm{Et}), 1.76$ $\left(n\right.$-Pr) and $\delta 1.88(\mathrm{Et}), 1.89\left(n\right.$-Pr). The ${ }^{13} \mathrm{C}-\mathrm{NMR}$ spectra of both complexes are also consistent with the proposed structure. Formation of these alkyl iminoacyl tantalum compounds demonstrates the presence of the dialkyl complexes at room temperature, and therefore indicates that alkylation of $\left[\mathrm{TaCp} * \mathrm{Cl}_{2}(\mathrm{NAr})\right]$ probably takes place to give the monoalkylated derivative in a first step, which is further transformed into the dialkyl compound before total decomposition occurs in the presence of phosphine.

To confirm the first step formation of the monoalkylated compounds [TaCp* $\mathrm{ClR}(\mathrm{NAr})]$ we decided to study the same reactions using one equiv. of the alkylating agent in the presence of the isocyanide in order to produce the insertion reaction before the dialkyl compounds could be formed. As shown in Scheme 2 addition of one equiv. of $\mathrm{MgClR}(\mathrm{R}=\mathrm{Et}, n-\mathrm{Pr}, i-\mathrm{Pr})$ under these conditions led to the chloro iminoacyl derivatives $\quad\left[\mathrm{TaCp} * \mathrm{Cl}\left\{\eta^{2}-\mathrm{CR}=\mathrm{N}\left(2,6-\mathrm{Me}_{2} \mathrm{C}_{6} \mathrm{H}_{3}\right)\right\}-\{\mathrm{N}-\right.$ $\left.\left.\left(2,6-\mathrm{Me}_{2} \mathrm{C}_{6} \mathrm{H}_{3}\right)\right\}\right](\mathrm{R}=\mathrm{Et} 5, n-\operatorname{Pr} \mathbf{6}, i$-Pr 7) isolated as pale yellow solids, showing that insertion of the isocyanide into the tantalum-alkyl bond of the monoalkylated compound formed in the first step is preferred to $\beta$-hydrogen abstraction and to alkylation of the second tantalum-chlorine bond. Complexes 5-7 were identified by their analytical composition and their formulation was consistent with their observed NMR behaviour. The methylenic protons of the alkyl group 


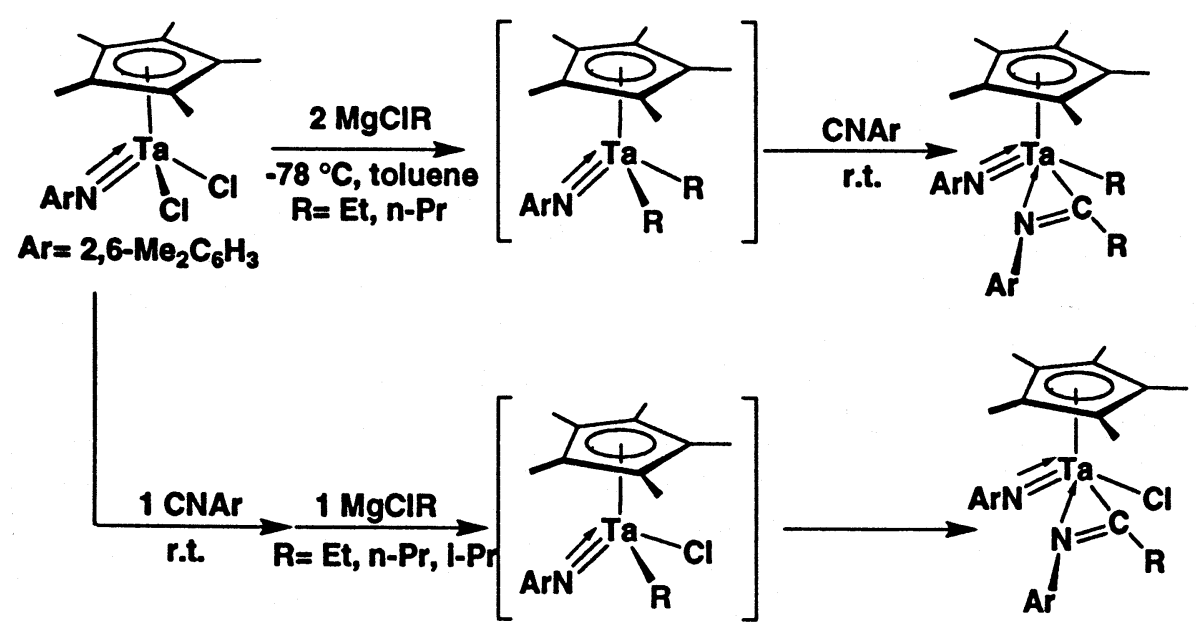

Scheme 2.

[ethyl (5); $n-\operatorname{Pr}(\mathbf{6})$ ] bonded to the iminoacyl carbon, the two methyl groups of the $i-\operatorname{Pr}(7)$ and the aryl imino substituents show the diastereotopic character due to the presence of the chiral metal center giving rise to NMR behaviour similar to that discussed above for the related alkyl complexes 3-4 (see Section 3).

\section{Experimental section}

All operations were carried out under a dry argon atmosphere either in a vacuum atmosphere Dri-lab or by standard Schlenck techniques. Hydrocarbon solvents were dried and freshly distilled: $n$-hexane from sodium potassium alloy, toluene from sodium and ether from sodium-benzophenone. Reagent grade $\mathrm{MgClR}(\mathrm{R}=$ Et, $n$-Pr, $i$-Pr $2.0 \mathrm{M}$ in THF, Aldrich), $\mathrm{PMe}_{3}(1.0 \mathrm{M}$ in toluene, Aldrich) and 2,6- $\mathrm{Me}_{2} \mathrm{C}_{6} \mathrm{H}_{3}$ (Fluka) were purchased form commercial sources and were used without further purification. The starting complex TaCp $* \mathrm{Cl}_{2}$ (NAr) [10] was prepared as described previously.

Infrared spectra were recorded on a Perkin-Elmer 583 spectrophotometer $\left(4000-200 \mathrm{~cm}^{-1}\right) \cdot{ }^{1} \mathrm{H},{ }^{13} \mathrm{C}$ and ${ }^{31} \mathrm{P}-\mathrm{NMR}$ spectra were recorded on a Varian Unity VXR $300 \mathrm{MHz}$ instrument, and chemical shifts were measured relative to residual ${ }^{1} \mathrm{H}$ and ${ }^{13} \mathrm{C}$ resonances in the deuterated solvents $\mathrm{C}_{6} \mathrm{D}_{6}(\delta 7.15), \mathrm{CDCl}_{3}(\delta 7.24)$ and $\mathrm{C}_{6} \mathrm{D}_{6}(\delta 128), \mathrm{CDCl}_{3}(\delta 77)$, respectively. Mass spectra were recorded on an HP 5988 A instrument. C, $\mathrm{H}$ and $\mathrm{N}$ analyses were carried out with a Perkin-Elmer 240C microanalyzer.

\subsection{Synthesis of $\left[\mathrm{Ta}\left(\eta^{5}-\mathrm{C}_{5} \mathrm{Me} \mathrm{e}_{5}\right)\left\{\mathrm{N}\left(2,6-\mathrm{Me}_{2} \mathrm{C}_{6} \mathrm{H}_{3}\right)\right\}\right.$} $\left.\left(\mathrm{CH}_{2}=\mathrm{CHR}\right)\left(\mathrm{PMe}_{3}\right)\right](\mathrm{R}=\mathrm{H} \mathrm{1}, \mathrm{Me} 2)$

THF solution of $\mathrm{MgClR}(\mathrm{R}=\mathrm{Et}, n-\mathrm{Pr})(1.00 \mathrm{mmol})$ and $\mathrm{PMe}_{3}(2.50 \mathrm{mmol})$ were added to diethylether (30 ml) solutions of $\left[\mathrm{Ta}\left(\eta^{5}-\mathrm{C}_{5} \mathrm{Me}_{5}\right) \mathrm{Cl}_{2}\left\{\mathrm{~N}\left(2,6-\mathrm{Me}_{2} \mathrm{C}_{6} \mathrm{H}_{3}\right)\right\}\right]$ $(0.25 \mathrm{~g}, 0.50 \mathrm{mmol})$ cooled to $-78^{\circ} \mathrm{C}$. After stirring for $0.5 \mathrm{~h}$ the solutions were warmed to room temperature and stirred for $1 \mathrm{~h}$. The resulting solutions were filtered and the solvent was removed by evaporation in vacuo leaving yellow oils which were crystallized from $n$-hexane and identified as complexes $1(0.23 \mathrm{~g}, 86 \%)$ and 2 $(0.20 \mathrm{~g}, 73 \%)$.

Data for complex 1: ${ }^{1} \mathrm{H}-\mathrm{NMR}(300 \mathrm{MHz}, \delta$, ppm in $\left.\mathrm{C}_{6} \mathrm{D}_{6}\right): 7.04\left(\mathrm{~d}, 2 \mathrm{H},{ }^{3} J_{\mathrm{HH}}=7.3 \mathrm{~Hz}, m-\mathrm{Me}_{2} \mathrm{C}_{6} \mathrm{H}_{3}\right), 6.78$ $\left(\mathrm{t}, \quad 1 \mathrm{H},{ }^{3} J_{\mathrm{HH}}=7.3 \mathrm{~Hz}, p-\mathrm{Me}_{2} \mathrm{C}_{6} \mathrm{H}_{3}\right), 2.41(\mathrm{~s}, 6 \mathrm{H}$, $\left.M e_{2} \mathrm{C}_{6} \mathrm{H}_{3}\right), 1.77\left(\mathrm{~s}, 15 \mathrm{H}, \mathrm{C}_{5} M e_{5}\right), 1.07\left(\mathrm{~s}, 9 \mathrm{H},{ }^{2} J_{\mathrm{HP}}=7.3\right.$ $\left.\mathrm{Hz}, \mathrm{PMe}_{3}\right),-0.18,0.82,1.02\left(\mathrm{~m}, 4 \mathrm{H}, \mathrm{C}_{2} H_{4}\right) .{ }^{13} \mathrm{C}-$ NMR $\left\{{ }^{1} \mathrm{H}\right\}\left(75 \mathrm{MHz}, \delta\right.$, ppm in $\left.\mathrm{C}_{6} \mathrm{D}_{6}\right): 156.0\left(C_{i p s o}-\right.$ $\left.\mathrm{Me}_{2} C_{6} \mathrm{H}_{3}\right), 131.8-119.0 \quad\left(\mathrm{Me}_{2} C_{6} \mathrm{H}_{3}\right), 107.7 \quad\left(C_{5} \mathrm{Me}_{5}\right)$, $35.4\left(C_{\text {endo }} \mathrm{C}_{2} \mathrm{H}_{4}\right), 28.9\left(C_{\text {exo }} \mathrm{C}_{2} \mathrm{H}_{4}\right), 19.8\left(M e_{2} \mathrm{C}_{6} \mathrm{H}_{3}\right)$, $16.2(\mathrm{PMe}), 10.6\left(\mathrm{C}_{5} \mathrm{Me}_{5}\right)$. MS (EI, $\left.10 \mathrm{eV}\right): m / e 539$ $\left(\left[\mathrm{M}^{+}\right], 8\right), 511$ (52), 435 (73), 121 (100). Anal. Calcd. for $\mathrm{C}_{23} \mathrm{H}_{37} \mathrm{NPTa}$ : C, 51.20; H, 6.93; N, 2.60. Found: C, $51.00 ; \mathrm{H}, 6.33 ; \mathrm{N}, 2.46 \%$.

Data for complex 2 (major isomer): ${ }^{1} \mathrm{H}-\mathrm{NMR}$ (300 $\mathrm{MHz}, \delta$, ppm in $\left.\mathrm{C}_{6} \mathrm{D}_{6}\right): 7.11-6.84\left(\mathrm{~m}, 3 \mathrm{H}, \mathrm{Me}_{2} \mathrm{C}_{6} \mathrm{H}_{3}\right)$, $2.44\left(\mathrm{~s}, 6 \mathrm{H}, \mathrm{Me}_{2} \mathrm{C}_{6} \mathrm{H}_{3}\right), 2.31\left(\mathrm{dd}, 3 \mathrm{H},{ }^{3} \mathrm{~J}_{\mathrm{H}-\mathrm{H}}=1.6 \mathrm{~Hz}\right.$, $\left.{ }^{3} J_{\mathrm{H}-\mathrm{H}_{\text {trans }}}=6.8 \mathrm{~Hz}, M e \mathrm{CH}=\mathrm{CH}_{2}\right), 1.72\left(\mathrm{~s}, 15 \mathrm{H}, \mathrm{C}_{5} M e_{5}\right)$, $1.12\left(\mathrm{~d}, 9 \mathrm{H},{ }^{2} J_{\mathrm{HP}}=7.3 \mathrm{~Hz}, \mathrm{PMe}_{3}\right)$. Data for complex 2 (minor isomer): ${ }^{1} \mathrm{H}-\mathrm{NMR}(300 \mathrm{MHz}, \delta, \mathrm{ppm}$ in $\left.\mathrm{C}_{6} \mathrm{D}_{6}\right): 7.10-6.70 \quad\left(\mathrm{~m}, 3 \mathrm{H}, \mathrm{Me}_{2} \mathrm{C}_{6} H_{3}\right), 2.37$ (s, 6H, $\left.M e_{2} \mathrm{C}_{6} \mathrm{H}_{3}\right), 1.81\left(\mathrm{~s}, 15 \mathrm{H}, \mathrm{C}_{5} M e_{5}\right), 1.14\left(\mathrm{~d}, 9 \mathrm{H},{ }^{2} J_{\mathrm{HP}}=\right.$ $7.3 \mathrm{~Hz}, \mathrm{PMe}_{3}$ ). The methine and methylene signals of propene group are unresolved. Anal. Calcd. for $\mathrm{C}_{24} \mathrm{H}_{39}$ NPTa: $\mathrm{C}, 52.09 ; \mathrm{H}, 7.12 ; \mathrm{N}, 2.53$. Found: $\mathrm{C}$, $51.85 ; \mathrm{H}, 6.93 ; \mathrm{N}, 2.40 \%$.

\subsection{Synthesis of $\left[T a\left(\eta^{5}-C_{5} M e_{5}\right) R\left\{\eta^{2}-C R=N(2,6-\right.\right.$ $\left.\left.\left.\mathrm{Me}_{2} \mathrm{C}_{6} \mathrm{H}_{3}\right)\right\}\left\{\mathrm{N}\left(2,6-\mathrm{Me}_{2} \mathrm{C}_{6} \mathrm{H}_{3}\right)\right\}\right](\mathrm{R}=\mathrm{Et} \mathbf{3}, n-\operatorname{Pr}$ 4)}

THF solutions of $\mathrm{MgClR}(\mathrm{R}=\mathrm{Et}, n-\mathrm{Pr})(1.00 \mathrm{mmol})$ were added to toluene solutions $(20 \mathrm{ml})$ of 
$\left[\mathrm{Ta}\left(\eta^{5}-\mathrm{C}_{5} \mathrm{Me}_{5}\right) \mathrm{Cl}_{2}\left\{\mathrm{~N}\left(2,6-\mathrm{Me}_{2} \mathrm{C}_{6} \mathrm{H}_{3}\right)\right\}\right] \quad(0.25 \quad \mathrm{~g}, \quad 0.50$ $\mathrm{mmol})$ cooled to $-78^{\circ} \mathrm{C}$. After stirring for $15 \mathrm{~min}$, $\mathrm{CN}\left(2,6-\mathrm{Me}_{2} \mathrm{C}_{6} \mathrm{H}_{3}\right)(0.07 \mathrm{mmol})$ dissolved in $20 \mathrm{ml}$ of toluene was added dropwise. The solutions were warmed to room temperature and stirred for $1 \mathrm{~h}$. The resulting solutions were filtered and the solvent was removed in vacuo. The residues were washed with $n$-hexane $(10 \mathrm{ml})$ and identified as complexes $3(0.27 \mathrm{~g}$, $89 \%)$ and $4(0.29 \mathrm{~g}, 91 \%)$.

Data for complex 3: ${ }^{1} \mathrm{H}-\mathrm{NMR}(300 \mathrm{MHz}, \delta$, ppm in $\left.\mathrm{C}_{6} \mathrm{D}_{6}\right): 7.12-6.72\left(\mathrm{~m}, 6 \mathrm{H}, \mathrm{Me}_{2} \mathrm{C}_{6} H_{3}\right), 2.89(\mathrm{~m}, 1 \mathrm{H}$, $\left.\eta^{2}-\mathrm{C}\left(\mathrm{CH}_{2} \mathrm{CH}_{3}\right)=\mathrm{NAr}\right), \quad 2.47 \quad\left(\mathrm{~m}, \quad 1 \mathrm{H}, \quad \eta^{2}-\right.$ $\left.\mathrm{C}\left(\mathrm{CH}_{2} \mathrm{CH}_{3}\right)=\mathrm{NAr}\right), 2.46\left(\mathrm{sbr}, 6 \mathrm{H}, \mathrm{Ta}=\mathrm{N}-\mathrm{Me}_{2} \mathrm{C}_{6} \mathrm{H}_{3}\right)$, $1.91\left(\mathrm{t}, 3 \mathrm{H},{ }^{3} J_{\mathrm{HH}}=6.9 \mathrm{~Hz}, \mathrm{Ta}-\mathrm{CH}_{2} \mathrm{CH}_{3}\right), 1.88(\mathrm{~s}, 3 \mathrm{H}$, $\left.\eta^{2}-\mathrm{CR}=\mathrm{N} M e_{2} \mathrm{C}_{6} \mathrm{H}_{3}\right), 1.83\left(\mathrm{~s}, 15 \mathrm{H}, \mathrm{C}_{5} M e_{5}\right), 1.71(\mathrm{~s}, 3 \mathrm{H}$, $\left.\eta^{2}-\mathrm{CR}=\mathrm{N} M e_{2} \mathrm{C}_{6} \mathrm{H}_{3}\right), 1.45\left(\mathrm{~m}, 1 \mathrm{H}, \mathrm{Ta}-\mathrm{CH}_{2} \mathrm{CH}_{3}\right), 0.89$ $\left(\mathrm{t}, 3 \mathrm{H},{ }^{3} J_{\mathrm{HH}}=7.60 \mathrm{~Hz}, \eta^{2}-\mathrm{C}\left(\mathrm{CH}_{2} \mathrm{CH}_{3}\right)=\mathrm{NAr}\right), 0.74(\mathrm{~m}$, $\left.1 \mathrm{H}, \mathrm{Ta}-\mathrm{CH}_{2} \mathrm{CH}_{3}\right) .{ }^{13} \mathrm{C}-\mathrm{NMR}\left\{{ }^{1} \mathrm{H}\right\}(75 \mathrm{MHz}, \delta$, ppm in $\left.\mathrm{C}_{6} \mathrm{D}_{6}\right): 246.0 \quad\left(\eta^{2}-\mathrm{CR}=\mathrm{NAr}\right), 155.2-119.7 \quad\left(\mathrm{Me}_{2} C_{6} \mathrm{H}_{3}\right)$, $112.7 \quad\left(C_{5} \mathrm{Me}_{5}\right), \quad 35.3 \quad\left(\mathrm{Ta}-\mathrm{CH}_{2} \mathrm{CH}_{3}\right), \quad 25.5 \quad\left(\eta^{2}-\right.$ $\left.\mathrm{C}\left(\mathrm{CH}_{2} \mathrm{CH}_{3}\right)=\mathrm{NAr}\right), 18.9\left(\mathrm{Ta}-\mathrm{CH}_{2} \mathrm{CH}_{3}\right), 18.7(\mathrm{Ta}=\mathrm{N}-$ $\left.M e_{2} \mathrm{C}_{6} \mathrm{H}_{3}\right), \quad 18.6 \quad\left(\eta^{2}-\mathrm{CR}=\mathrm{N} M e_{2} \mathrm{C}_{6} \mathrm{H}_{3}\right), \quad 18.3$ $\left(\eta^{2}-\mathrm{CR}=\mathrm{N} M e_{2} \mathrm{C}_{6} \mathrm{H}_{3}\right), \quad 11.1 \quad\left(\mathrm{C}_{5} M e_{5}\right), \quad 10.1 \quad\left(\eta^{2}-\right.$ $\left.\mathrm{C}\left(\mathrm{CH}_{2} \mathrm{CH}_{3}\right)=\mathrm{NAr}\right)$. IR $\left(\mathrm{KBr} ; v, \mathrm{~cm}^{-1}\right): 1631$ (s), 1328 (s), 980 (m), 349 (m). MS (EI, $10 \mathrm{eV}): m / e 624\left(\left[\mathrm{M}^{+}\right]\right.$, 26), 595 (100), 435 (20). Anal. Calcd. for $\mathrm{C}_{31} \mathrm{H}_{43} \mathrm{~N}_{2} \mathrm{Ta}$ : C, 59.60; H, 6.95; N, 4.49. Found: C, 59.30; H, 6.73; N, $4.36 \%$.

Data for complex 4: ${ }^{1} \mathrm{H}-\mathrm{NMR}(300 \mathrm{MHz}, \delta$, ppm in $\left.\mathrm{C}_{6} \mathrm{D}_{6}\right): 7.10-6.65\left(\mathrm{~m}, 6 \mathrm{H}, \mathrm{Me}_{2} \mathrm{C}_{6} H_{3}\right), 3.01(\mathrm{~m}, 1 \mathrm{H}$, $\left.\eta^{2}-\mathrm{C}\left(\mathrm{CH}_{2} \mathrm{CH}_{2} \mathrm{CH}_{3}\right)=\mathrm{NAr}\right), \quad 2.58 \quad\left(\mathrm{~m}, \quad 1 \mathrm{H}, \quad \eta^{2}-\right.$ $\left.\mathrm{C}\left(\mathrm{CH}_{2} \mathrm{CH}_{2} \mathrm{CH}_{3}\right)=\mathrm{NAr}\right), \quad 2.47 \quad(\mathrm{sbr}, \quad 6 \mathrm{H}, \quad \mathrm{Ta}=\mathrm{N}-$ $\left.M e_{2} \mathrm{C}_{6} \mathrm{H}_{3}\right), 1.89\left(\mathrm{~s}, 3 \mathrm{H}, \eta^{2}-\mathrm{CR}=\mathrm{N} M e_{2} \mathrm{C}_{6} \mathrm{H}_{3}\right), 1.86(\mathrm{~s}$, $\left.15 \mathrm{H}, \mathrm{C}_{5} M e_{5}\right), 1.76\left(\mathrm{~s}, 3 \mathrm{H}, \eta^{2}-\mathrm{CR}=\mathrm{N} M e_{2} \mathrm{C}_{6} \mathrm{H}_{3}\right), 1.41(\mathrm{~m}$, $1 \mathrm{H}, \mathrm{Ta}-\mathrm{CH}_{2} \mathrm{CH}_{2} \mathrm{CH}_{3}$ ), 1.20 (sbr, $4 \mathrm{H}, \mathrm{Ta}-\mathrm{CH}_{2} \mathrm{CH}_{2} \mathrm{CH}_{3}$ and $\left.\eta^{2}-\mathrm{C}\left(\mathrm{CH}_{2} \mathrm{CH}_{2} \mathrm{CH}_{3}\right)=\mathrm{NAr}\right), 1.15\left(\mathrm{t}, 3 \mathrm{H},{ }^{3} \mathrm{~J}_{\mathrm{HH}}=7.3\right.$ $\left.\mathrm{Hz}, \quad \mathrm{Ta}-\mathrm{CH}_{2} \mathrm{CH}_{2} \mathrm{CH}_{3}\right), \quad 0.80 \quad(\mathrm{~m}, \quad 1 \mathrm{H}, \quad \mathrm{Ta}-$ $\left.\mathrm{CH}_{2} \mathrm{CH}_{2} \mathrm{CH}_{3}\right), 0.66 \quad\left(\mathrm{t}, 3 \mathrm{H},{ }^{3} J_{\mathrm{HH}}=7.29 \mathrm{~Hz}, \eta^{2}-\right.$ $\left.\mathrm{C}\left(\mathrm{CH}_{2} \mathrm{CH}_{2} \mathrm{CH}_{3}\right)=\mathrm{NAr}\right) .{ }^{13} \mathrm{C}-\mathrm{NMR}\left\{{ }^{1} \mathrm{H}\right\} \quad(75 \mathrm{MHz}, \delta$, $\mathrm{ppm}$ in $\left.\mathrm{C}_{6} \mathrm{D}_{6}\right): 245.1 \quad\left(\eta^{2}-\mathrm{CR}=\mathrm{NAr}\right), 155.2-120.9$ $\left(\mathrm{Me}_{2} \mathrm{C}_{6} \mathrm{H}_{3}\right), 112.2\left(C_{5} \mathrm{Me}_{5}\right), 47.3\left(\mathrm{Ta}-\mathrm{CH}_{2} \mathrm{CH}_{2} \mathrm{CH}_{3}\right)$, $38.8 \quad\left(\eta^{2}-\mathrm{C}\left(\mathrm{CH}_{2} \mathrm{CH}_{2} \mathrm{CH}_{3}\right)=\mathrm{NAr}\right), \quad 25.2 \quad(\mathrm{Ta}-$ $\left.\mathrm{CH}_{2} \mathrm{CH}_{2} \mathrm{CH}_{3}\right), 23.6\left(\eta^{2}-\mathrm{C}\left(\mathrm{CH}_{2} \mathrm{CH}_{2} \mathrm{CH}_{3}\right)=\mathrm{NAr}\right), 19.3$ $\left(\mathrm{Ta}-\mathrm{CH}_{2} \mathrm{CH}_{2} \mathrm{CH}_{3}\right), 18.5\left(\mathrm{Ta}=\mathrm{N}-\mathrm{Me}_{2} \mathrm{C}_{6} \mathrm{H}_{3}\right), 18.7\left(\eta^{2}-\right.$ $\left.\mathrm{CR}=\mathrm{N} M e_{2} \mathrm{C}_{6} \mathrm{H}_{3}\right), 18.4\left(\eta^{2}-\mathrm{CR}=\mathrm{N} M e_{2} \mathrm{C}_{6} \mathrm{H}_{3}\right), 14.1\left(\eta^{2}-\right.$ $\left.\mathrm{C}\left(\mathrm{CH}_{2} \mathrm{CH}_{2} \mathrm{CH}_{3}\right)=\mathrm{NAr}\right), 11.2\left(\mathrm{C}_{5} M e_{5}\right)$. IR $(\mathrm{KBr}, v$, $\mathrm{cm}^{-1}$ ): 1633 (s), 1326 (s), 981 (m), 347 (m). MS (EI, 10 $\mathrm{eV}): m / e 652$ ([M+ $\left.\left.\mathrm{M}^{+}\right], 12\right), 609$ (71), 174 (94), 105 (100). Anal. Calcd for $\mathrm{C}_{33} \mathrm{H}_{47} \mathrm{~N}_{2}$ Ta: $\mathrm{C}, 60.72 ; \mathrm{H}, 7.27 ; \mathrm{N}$, 4.29. Found: C, $60.55 ; \mathrm{H}, 7.12$; N, $4.06 \%$.

3.3. Synthesis of $\left[\mathrm{Ta}\left(\eta^{5}-\mathrm{C}_{5} \mathrm{Me} \mathrm{e}_{5}\right) \mathrm{Cl}\left\{\eta^{2}-\mathrm{CR}=\mathrm{N}(2,6-\right.\right.$ $\left.\left.\left.\mathrm{Me}_{2} \mathrm{C}_{6} \mathrm{H}_{3}\right)\right\}\left\{\mathrm{N}\left(2,6-\mathrm{Me}_{2} \mathrm{C}_{6} \mathrm{H}_{3}\right)\right\}\right](\mathrm{R}=\mathrm{Et}$ 5, n-Pr 6, i-Pr 7)

Solutions of $\mathrm{MgClR}(\mathrm{R}=\mathrm{Et}, n-\operatorname{Pr}, i-\operatorname{Pr})(0.05 \mathrm{mmol})$ in toluene $(15 \mathrm{ml})$ were added dropwise to a toluene solution $(20 \mathrm{ml})$ of a mixture of $\left[\mathrm{Ta}\left(\eta^{5}-\right.\right.$ $\left.\left.\mathrm{C}_{5} \mathrm{Me}_{5}\right) \mathrm{Cl}_{2}\left\{\mathrm{~N}\left(2,6-\mathrm{Me}_{2} \mathrm{C}_{6} \mathrm{H}_{3}\right)\right\}\right](0.25 \mathrm{~g}, 0.50 \mathrm{mmol})$ and $\mathrm{CN}\left(2,6-\mathrm{Me}_{2} \mathrm{C}_{6} \mathrm{H}_{3}\right)(0.07 \mathrm{mmol})$. After stirring for $1 \mathrm{~h}$ at room temperature the solutions were filtered and the solvent was removed in vacuo. The residues were washed with $n$-hexane $(10 \mathrm{ml})$ and identified as complexes $5(0.27 \mathrm{~g}, 87 \%), 6(0.28 \mathrm{~g}, 89 \%)$ and $7(0.29 \mathrm{~g}$, 93\%).

Data for complex 5: ${ }^{1} \mathrm{H}-\mathrm{NMR}(300 \mathrm{MHz}, \delta$, ppm in $\left.\mathrm{C}_{6} \mathrm{D}_{6}\right)$ : 7.11-6.65 (m, 6H, $\left.\mathrm{Me}_{2} \mathrm{C}_{6} H_{3}\right), 2.78(\mathrm{~m}, 1 \mathrm{H}$, $\left.\eta^{2}-\mathrm{C}\left(\mathrm{CH}_{2} \mathrm{CH}_{3}\right)=\mathrm{NAr}\right), \quad 2.55 \quad\left(\mathrm{~m}, \quad 1 \mathrm{H}, \quad \eta^{2}-\right.$ $\left.\mathrm{C}\left(\mathrm{CH}_{2} \mathrm{CH}_{3}\right)=\mathrm{NAr}\right), 2.50\left(\mathrm{sbr}, 6 \mathrm{H}, \mathrm{Ta}=\mathrm{N}-\mathrm{Me}_{2} \mathrm{C}_{6} \mathrm{H}_{3}\right)$, $1.93\left(\mathrm{~s}, 15 \mathrm{H}, \mathrm{C}_{5} M e_{5}\right), 1.89\left(\mathrm{~s}, 3 \mathrm{H}, \eta^{2}-\mathrm{CR}=\mathrm{N} M e_{2} \mathrm{C}_{6} \mathrm{H}_{3}\right)$, $1.79\left(\mathrm{~s}, 3 \mathrm{H}, \eta^{2}-\mathrm{CR}=\mathrm{N} M e_{2} \mathrm{C}_{6} \mathrm{H}_{3}\right), 0.76\left(\mathrm{t}, 3 \mathrm{H},{ }^{3} J_{\mathrm{HH}}=\right.$ $\left.7.32 \mathrm{~Hz}, \quad \eta^{2}-\mathrm{C}\left(\mathrm{CH}_{2} \mathrm{CH}_{3}\right)=\mathrm{NAr}\right) .{ }^{13} \mathrm{C}-\mathrm{NMR}\left\{{ }^{1} \mathrm{H}\right\} \quad(75$ $\mathrm{MHz}, \delta$, ppm in $\left.\mathrm{C}_{6} \mathrm{D}_{6}\right): 242.0\left(\eta^{2}-\mathrm{CR}=\mathrm{NAr}\right), 153.8-$ $119.3 \quad\left(\mathrm{Me}_{2} C_{6} \mathrm{H}_{3}\right), \quad 115.6 \quad\left(C_{5} \mathrm{Me}_{5}\right), \quad 29.9 \quad\left(\eta^{2}-\right.$ $\left.\mathrm{C}\left(\mathrm{CH}_{2} \mathrm{CH}_{3}\right)=\mathrm{NAr}\right), \quad 19.9 \quad\left(\mathrm{Ta}=\mathrm{N}-\mathrm{Me}_{2} \mathrm{C}_{6} \mathrm{H}_{3}\right), \quad 18.7$ $\left(\eta^{2}-\mathrm{CR}=\mathrm{N} M e_{2} \mathrm{C}_{6} \mathrm{H}_{3}\right), \quad 18.4 \quad\left(\eta^{2}-\mathrm{CR}=\mathrm{N} M e_{2} \mathrm{C}_{6} \mathrm{H}_{3}\right), \quad 11.3$ $\left(\mathrm{C}_{5} \mathrm{Me}_{5}\right), 9.2\left(\eta^{2}-\mathrm{C}\left(\mathrm{CH}_{2} \mathrm{CH}_{3}\right)=\mathrm{NAr}\right)$. IR $\left(\mathrm{KBr} ; v, \mathrm{~cm}^{-1}\right)$ : 1610 (s), 1327 (s), 982 (m), 356 (m), 306(m). MS (EI, 10 $\mathrm{eV}): \mathrm{m} / \mathrm{e} 630\left(\left[\mathrm{M}^{+}\right], 39\right), 601$ (64), 595 (11), 470 (58), 160 (100), 105 (39). Anal. Calcd for $\mathrm{C}_{29} \mathrm{H}_{38} \mathrm{ClN}_{2} \mathrm{Ta}$ : C, $55.20 ; \mathrm{H}, 6.08 ; \mathrm{N}, 4.44$. Found: C, 54.95; H, 6.00; N, $4.30 \%$.

Data for complex 6: ${ }^{1} \mathrm{H}-\mathrm{NMR}(300 \mathrm{MHz}, \delta$, ppm in $\left.\mathrm{C}_{6} \mathrm{D}_{6}\right): 7.10-6.65\left(\mathrm{~m}, 6 \mathrm{H}, \mathrm{Me}_{2} \mathrm{C}_{6} H_{3}\right), 2.86(\mathrm{~m}, 1 \mathrm{H}$, $\left.\eta^{2}-\mathrm{C}\left(\mathrm{CH}_{2} \mathrm{CH}_{2} \mathrm{CH}_{3}\right)=\mathrm{NAr}\right), \quad 2.75 \quad\left(\mathrm{~m}, \quad 1 \mathrm{H}, \quad \eta^{2}-\right.$ $\left.\mathrm{C}\left(\mathrm{CH}_{2} \mathrm{CH}_{2} \mathrm{CH}_{3}\right)=\mathrm{NAr}\right), \quad 2.47 \quad(\mathrm{sbr}, \quad 6 \mathrm{H}, \quad \mathrm{Ta}=\mathrm{N}-$ $\left.M e_{2} \mathrm{C}_{6} \mathrm{H}_{3}\right), 1.95$ (s, $\left.15 \mathrm{H}, \mathrm{C}_{5} M e_{5}\right), 1.87 \quad(\mathrm{~s}, \quad 3 \mathrm{H}$, $\left.\eta^{2}-\mathrm{CR}=\mathrm{N} M e_{2} \mathrm{C}_{6} \mathrm{H}_{3}\right), 1.82\left(\mathrm{~s}, 3 \mathrm{H}, \eta^{2}-\mathrm{CR}=\mathrm{N} M e_{2} \mathrm{C}_{6} \mathrm{H}_{3}\right)$, 1.32 (sbr, $\left.2 \mathrm{H}, \eta^{2}-\mathrm{C}\left(\mathrm{CH}_{2} \mathrm{CH}_{2} \mathrm{CH}_{3}\right)=\mathrm{NAr}\right), 0.57(\mathrm{t}, 3 \mathrm{H}$, $\left.{ }^{3} J_{\mathrm{HH}}=7.32 \quad \mathrm{~Hz}, \quad \eta^{2}-\mathrm{C}\left(\mathrm{CH}_{2} \mathrm{CH}_{2} \mathrm{CH}_{3}\right)=\mathrm{NAr}\right) .{ }^{13} \mathrm{C}-$ NMR $\left\{{ }^{1} \mathrm{H}\right\} \quad\left(75 \mathrm{MHz}, \delta\right.$, ppm in $\left.\mathrm{C}_{6} \mathrm{D}_{6}\right): 241.0\left(\eta^{2}-\right.$ $C \mathrm{R}=\mathrm{NAr}), \quad 153.7-125.3 \quad\left(\mathrm{Me}_{2} C_{6} \mathrm{H}_{3}\right), 115.2 \quad\left(C_{5} \mathrm{Me}_{5}\right)$, $39.1 \quad\left(\eta^{2}-\mathrm{C}\left(\mathrm{CH}_{2} \mathrm{CH}_{2} \mathrm{CH}_{3}\right)=\mathrm{NAr}\right), \quad 19.9 \quad\left(\eta^{2}-\right.$ $\left.\mathrm{C}\left(\mathrm{CH}_{2} \mathrm{CH}_{2} \mathrm{CH}_{3}\right)=\mathrm{NAr}\right), 19.1 \quad\left(\mathrm{Ta}=\mathrm{N}-\mathrm{Me}_{2} \mathrm{C}_{6} \mathrm{H}_{3}\right), 18.7$ $\left(\eta^{2}-\mathrm{CR}=\mathrm{N} M e_{2} \mathrm{C}_{6} \mathrm{H}_{3}\right), \quad 18.4 \quad\left(\eta^{2}-\mathrm{CR}=\mathrm{N} M e_{2} \mathrm{C}_{6} \mathrm{H}_{3}\right), \quad 14.7$ $\left(\eta^{2}-\mathrm{C}\left(\mathrm{CH}_{2} \mathrm{CH}_{2} \mathrm{CH}_{3}\right)=\mathrm{NAr}\right), 11.3\left(\mathrm{C}_{5} M e_{5}\right)$. IR $(\mathrm{KBr}, v$, $\mathrm{cm}^{-1}$ ): 1628 (s), 1328 (s), $983(\mathrm{~m}), 357(\mathrm{~m}), 302(\mathrm{~m})$. MS (EI, $10 \mathrm{eV}): m / e 644\left(\left[\mathrm{M}^{+}\right], 3\right), 601$ (5), 470 (10), 174 (100), 105 (37). Anal. Calcd for $\mathrm{C}_{30} \mathrm{H}_{40} \mathrm{ClN}_{2} \mathrm{Ta}$ : C, 55.85; H, 6.23; N, 4.34. Found: C, 55.80; H, 6.13; N, $4.31 \%$.

Data for complex 7: ${ }^{1} \mathrm{H}-\mathrm{NMR}(300 \mathrm{MHz}, \delta$, ppm in $\left.\mathrm{C}_{6} \mathrm{D}_{6}\right)$ : 7.10-6.65 (m, 6H, $\left.\mathrm{Me}_{2} \mathrm{C}_{6} H_{3}\right), 3.05(\mathrm{~m}, 1 \mathrm{H}$, $\left.\eta^{2}-\mathrm{C}\left[\mathrm{CH}\left(\mathrm{CH}_{3}\right)_{2}\right]=\mathrm{NAr}\right), \quad 2.50 \quad(\mathrm{sbr}, \quad 6 \mathrm{H}, \quad \mathrm{Ta}=\mathrm{N}-$ $\left.M e_{2} \mathrm{C}_{6} \mathrm{H}_{3}\right), 1.96\left(\mathrm{~s}, 15 \mathrm{H}, \mathrm{C}_{5} M e_{5}\right), 1.95\left(\mathrm{~s}, 3 \mathrm{H}, \eta^{2}-\right.$ $\left.\mathrm{CR}=\mathrm{N} M e_{2} \mathrm{C}_{6} \mathrm{H}_{3}\right), 1.80\left(\mathrm{~s}, 3 \mathrm{H}, \eta^{2}-\mathrm{CR}=\mathrm{N} M e_{2} \mathrm{C}_{6} \mathrm{H}_{3}\right), 0.97$ $\left(\mathrm{d}, 6 \mathrm{H},{ }^{3} \mathrm{~J}_{\mathrm{HH}}=7.32 \mathrm{~Hz}, \eta^{2}-\mathrm{C}\left[\mathrm{CH}\left(\mathrm{CH}_{3}\right)_{2}\right]=\mathrm{NAr}\right) .{ }^{13} \mathrm{C}-$ NMR $\left\{{ }^{1} \mathrm{H}\right\} \quad\left(75 \mathrm{MHz}, \delta\right.$, ppm in $\left.\mathrm{C}_{6} \mathrm{D}_{6}\right): 243.0\left(\eta^{2}-\right.$ $C \mathrm{R}=\mathrm{NAr}), \quad 153.6-125.9 \quad\left(\mathrm{Me}_{2} C_{6} \mathrm{H}_{3}\right), 115.8 \quad\left(C_{5} \mathrm{Me}_{5}\right)$, $36.4\left(\eta^{2}-\mathrm{C}\left[\mathrm{CH}\left(\mathrm{CH}_{3}\right)_{2}\right]=\mathrm{NAr}\right), 19.9\left(\mathrm{Ta}=\mathrm{N}-\mathrm{Me}_{2} \mathrm{C}_{6} \mathrm{H}_{3}\right)$, 
$19.1\left(\eta^{2}-\mathrm{C}\left[\mathrm{CH}\left(\mathrm{CH}_{3}\right)_{2}\right]=\mathrm{NAr}\right), \quad 18.9 \quad\left(\eta^{2}-\mathrm{C}\left[\mathrm{CH}\left(\mathrm{CH}_{3}\right)_{2}\right]=\right.$ $\mathrm{NAr}), \quad 18.7 \quad\left(\eta^{2}-\mathrm{CR}=\mathrm{N} M e_{2} \mathrm{C}_{6} \mathrm{H}_{3}\right), \quad 18.3 \quad\left(\eta^{2}-\mathrm{CR}=\right.$ $\left.\mathrm{N} M e_{2} \mathrm{C}_{6} \mathrm{H}_{3}\right), 11.4\left(\mathrm{C}_{5} M e_{5}\right)$. IR ( $\left.\mathrm{KBr}, v, \mathrm{~cm}^{-1}\right): 1631(\mathrm{~s})$, $1324(\mathrm{~s}), 983(\mathrm{~m}), 357(\mathrm{~m}), 301(\mathrm{~m})$. MS (EI, $10 \mathrm{eV})$ : $m / e 644\left(\left[\mathrm{M}^{+}\right], 5\right), 601$ (20), 470 (21), 174 (100), 105 (57). Anal. Calcd for $\mathrm{C}_{30} \mathrm{H}_{40} \mathrm{ClN}_{2}$ Ta: $\mathrm{C}, 55.85 ; \mathrm{H}, 6.26$; $\mathrm{N}, 4.34$. Found: C, 55.72; H, 6.23; N, 4.26\%.

\subsection{X-ray data collection, structure determination and refinement for complex 1.}

The crystallographic data of complex 1 are summarized in Table 2. Data were collected at room temperature $\left(22^{\circ} \mathrm{C}\right)$ on a Siemens AED diffractometer, using the graphite-monochromated $\mathrm{Mo}-\mathrm{K}_{\alpha}$ radiation and the $\theta / 2 \theta$ scan type. One standard reflection was monitored every 100 measurements; no significant decay was noticed over the time of data collection. Intensities were corrected for Lorentz and polarization effects. A correction for absorption was applied (maximum and minimum value for the transmission coefficient was 1.000 and 0.523 [11]).

The structure was solved by Patterson and Fourier methods and refined by full-matrix least-squares first with isotropic thermal parameters and then with anisotropic thermal parameters for all non-hydrogen atoms. All hydrogen atoms were placed at their geometrically calculated positions $(\mathrm{C}-\mathrm{H}=0.96 \AA)$ and refined 'riding' on the corresponding parent atoms, excepting those of the ethylene molecule which were clearly found in the $\Delta F$ map and refined isotropically. The final cycles of refinement were carried out on the

Table 2

Summary of crystallographic data for complex 1

\begin{tabular}{ll}
\hline Formula & $\mathrm{C}_{23} \mathrm{H}_{37} \mathrm{NPTa}$ \\
Mol. wt. & 539.47 \\
Crystal system & Triclinic \\
Space group & $\mathrm{P} \overline{1}$ \\
$a, \AA$ & $8.659(3)$ \\
$b, \AA$ & $10.807(4)$ \\
$c, \AA$ & $13.373(4)$ \\
$\alpha,^{\circ}$ & $94.06(2)$ \\
$\beta,^{\circ}$ & $101.70(2)$ \\
$\gamma^{\circ}$ & $107.23(2)$ \\
$V, \AA^{3}$ & $31158.9(7)$ \\
$Z$ & 2 \\
$D_{\text {calc }}, \mathrm{g} \mathrm{cm}^{-3}$ & 1.546 \\
$F(000)$ & 540 \\
Crystal size, mm & $0.20 \times 0.20 \times 0.35$ \\
$\mu\left(\right.$ Mo $\left.-\mathrm{K}_{\alpha}\right), \mathrm{cm}^{-1}$ & 48.18 \\
$\theta$ range, & $3-30$ \\
Unique total data & 6755 \\
Unique observed data & $5175[I>3 \sigma(I)]$ \\
$R=\sum|\Delta F| \sum\left|F_{\mathrm{o}}\right|$ & 0.0386 \\
$R_{w}=\left\lceil\sum^{\frac{1}{1}}(\Delta F)^{2} / \sum w F_{\mathrm{o}}^{2}\right.$ & 0.0454 \\
\hline
\end{tabular}

Table 3

Atomic coordinates $\left(\times 10^{4}\right)$ and equivalent isotropic displacement parameters $\left(\AA^{2} \times 10^{4}\right)$ for complex 1

\begin{tabular}{|c|c|c|c|c|}
\hline & $x$ & $y$ & $z$ & $U_{\mathrm{a}}$ \\
\hline Та & $532.2(3$ & $3316.2(2)$ & 2131.1(2) & $389(1)$ \\
\hline & ) & & & \\
\hline$P$ & $2061(2)$ & $2786(2)$ & $3797(1)$ & $494(5)$ \\
\hline $\mathrm{N}$ & $1920(6)$ & $5011(4)$ & $2466(3)$ & $426(16)$ \\
\hline $\mathrm{C}(1)$ & $-1101(8)$ & $2218(6)$ & 406(4) & $523(21)$ \\
\hline$C(2)$ & $-1313(8)$ & $1176(6)$ & 1009(4) & $500(20)$ \\
\hline C(3) & $250(8)$ & $1016(6)$ & $1357(4)$ & $532(23)$ \\
\hline$C(4)$ & $1466(8)$ & 1975(6) & 994(5) & $522(22)$ \\
\hline$C(5)$ & $601(8)$ & $2708(6)$ & 381(4) & $508(22)$ \\
\hline C(6) & $-2533(10)$ & $2555(8)$ & $-286(6)$ & $777(34)$ \\
\hline$C(7)$ & $-2964(9)$ & $368(7)$ & 1192(6) & $735(30)$ \\
\hline $\mathrm{C}(8)$ & $543(11)$ & $-110(7)$ & $1874(6)$ & $777(34)$ \\
\hline$C(9)$ & $3255(10)$ & 2034(9) & 1071(7) & $840(38)$ \\
\hline$C(10)$ & $1305(11)$ & $3678(8)$ & $-294(6)$ & $803(36)$ \\
\hline $\mathrm{C}(11)$ & $3005(7)$ & $6262(5)$ & $2772(4)$ & 432(19) \\
\hline $\mathrm{C}(12)$ & $2506(9)$ & $7224(6)$ & $3297(5)$ & $560(25)$ \\
\hline C(13) & $3592(11)$ & $8485(7)$ & $3623(6)$ & $692(30)$ \\
\hline$C(14)$ & $5180(12)$ & $8823(7)$ & $3446(6)$ & $812(35)$ \\
\hline$C(15)$ & $5689(9)$ & $7905(7)$ & $2955(6)$ & $686(28)$ \\
\hline$C(16)$ & $4623(8)$ & $6622(6)$ & $2610(5)$ & $549(23)$ \\
\hline $\mathrm{C}(17)$ & 767(10) & $6880(8)$ & $3483(7)$ & $762(36)$ \\
\hline C(18) & $5212(9)$ & $5652(8)$ & $2085(6)$ & $719(32)$ \\
\hline C(19) & $-1870(8)$ & $3623(7)$ & $2235(7)$ & $684(29)$ \\
\hline$C(20)$ & $-1310(8)$ & $3060(7)$ & $3126(6)$ & $667(28)$ \\
\hline $\mathrm{C}(21)$ & $2587(11)$ & $4153(7)$ & $4820(5)$ & $724(31)$ \\
\hline$C(22)$ & 4111(9) & $2537(8)$ & $3882(6)$ & $718(31)$ \\
\hline$C(23)$ & $993(11)$ & $1405(7)$ & $4398(5)$ & $759(32)$ \\
\hline
\end{tabular}

a Equivalent isotropic $U$ defined as one-third of the trace of the orthogonalized $U_{i j}$ tensor.

basis of 251 variables. A weighting scheme $w=\left[\sigma^{2} F_{\mathrm{o}}+\right.$ $\left.g F_{\mathrm{o}}^{2}\right]^{-1}$ was used in the last cycles of refinement with $g=0.0004$ at convergence. Final $R$ and $R_{w}$ values were 0.0386 and 0.0454 , respectively. The analytical scattering factors, corrected for the real and imaginary parts of anomalous dispersions, were taken from ref. [12]. All calculations were carried out on the ENCORE 91 of the 'Centro di Studio per la Strutturistica Diffrattometrica" del C.N.R., Parma, using the SHELX-76 and SHELXS-86 systems of crystallographic computer programs [13]. The final atomic coordinates for the nonhydrogen atoms are given in Table 3. Additional data (atomic coordinates of the hydrogen atoms, thermal parameters) have been deposited at the Cambridge Crystallographic Data Centre or are available from the authors.

\section{Acknowledgements}

The authors are grateful to DGICYT (Project PB9201178C) and Consiglio Nazionale delle Ricerche (Rome) for financial supports. J.S.-N. acknowledges MEC for a fellowship. 


\section{References}

[1] D.N. Williams, J.P. Mitchell, A.D. Poole, V. Siemeling, W. Clegg, D.C.R. Hockless, P.A. O’Neil, V.C. Gibson, J. Chem. Soc., Dalton Trans. (1992) 739.

[2] (a) E. Negishi, in: L. Paquette (Ed.), Comprehensive Organic Synthesis, vol. 5, Pergamon, NY, 1991, p. 1163. (b) S.L. Buchwald, R.B. Nielsen, Chem. Rev. 88 (1988) 1047. (c) E. Negishi, T. Takahashi, Acc. Chem. Res. 27 (1994) 124. (d) R.D. Broene, S.L. Buchwald, Science 261 (1993) 1696.

[3] (a) R.F. Jordan, Adv. Organomet. Chem. 32 (1991) 325. (b) W. Kaminsky, Catal. Today 20 (1994) 257. (c) W.M. Kelly, N.J. Taylor, S. Collins, Macromolecules 27 (1994) 4477. (d) G.W. Coates, R.M. Waymouth, J. Am. Chem. Soc. 113 (1991) 6270. (e) T.D. Tilley, Acc. Chem. Res. 26 (1993) 22. (f) S. Bourg, R.J.P. Corrin, M. Enders, J.J. Moreau, Organometallics 14 (1995) 564.

[4] F.J. Fernández, P. Gómez-Sal, A. Manzanero, P. Royo, H. Jacobsen, H. Berke, Organometallics 16 (1997) 1553.

[5] (a) W.A. Nugent, J.M. Mayer, Metal Ligand Multiple Bonds. Wiley Interscience, NY, 1988. (b) D.E. Wigley, Prog. Inorg. Chem.42 (1994) 239.
[6] J.D. Burrington, R.K. Grasselli, Adv. Catal. 30 (1981) 133.

[7] (a) A.D. Poole, V.C. Gibson, W. Clegg, J. Chem. Soc., Chem. Commun. (1992) 237. (b) J.-K.F. Buijink, J.H. Teuben, H. Koojman, A.L. Spek, Organometallics 13 (1994) 2922.

[8] (a) M.V. Galakhov, M. Gómez, G. Jiménez, M.A. Pellinghelli, P. Royo, A. Tiripicchio, Organometallics 13(1994) 1564. (b) M.V. Galakhov, M. Gómez, G. Jiménez, P. Royo, M.A. Pellinghelli, A. Tiripicchio, Organometallics 14 (1995) 2843.

[9] (a) L.D. Durfee, I.P. Rothwell, Chem. Rev. 88 (1988) 1059. (b) M.V. Galakhov, M. Gómez, G. Jiménez, P. Royo, M.A. Pellinghelli, A. Tiripicchio, Organometallics 14 (1995) 1901. (c) M. Gómez, P. Gómez-Sal, G. Jiménez, A. Martín, P. Royo, J. Sánchez-Nieves, Organometallics 15 (1996) 3579.

[10] T.C. Baldwin, S.R. Huber, M.A. Bruck, D.E. Wigley, Inorg. Chem. 32 (1993) 5682.

[11] (a) N. Walker, D. Stuart, Acta Crystallogr., Sect. A 39 (1983) 158. (b) F. Ugozzoli, Comput. Chem. 11 (1987) 109.

[12] International Tables for X-Ray Crystallography, Vol IV, Kynoch Press, Birmingham, England, 1974.

[13] (a) G.M. Sheldrick, SHELX-76 Program for crystal structure determination, University of Cambridge, England, 1976. (b) SHELXS-86 Program for the solution of crystal structures, University of Göttingen, 1986. 